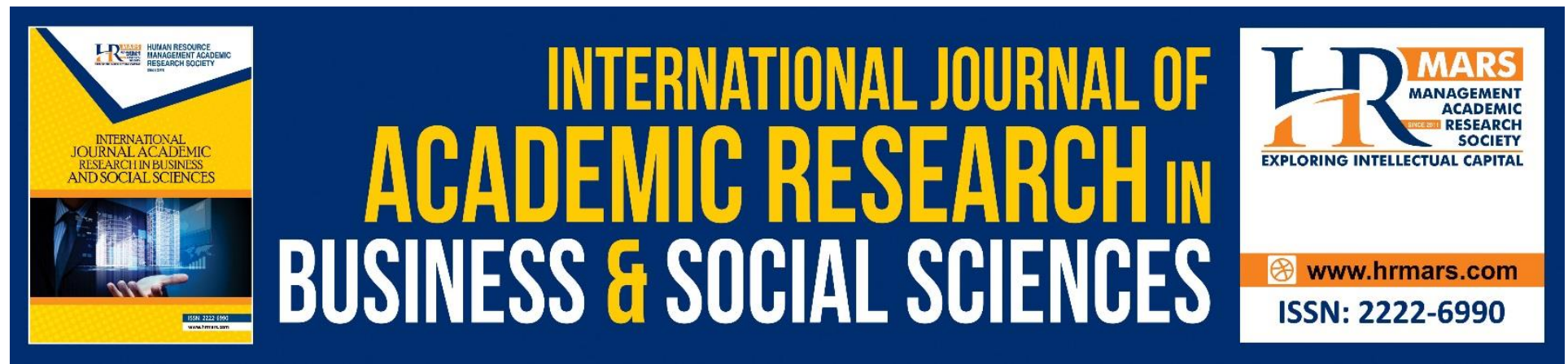

\title{
A Study on Autonomous Use of Technology for Language Learning Among ESL Learners at Tertiary Level
}

Noraini Zulkepli, Siti Nor Amalina Ahmad Tajuddin, Azizah Atan, Farah Natchiar Mohd Khaja

To Link this Article: http://dx.doi.org/10.6007/IJARBSS/v8-i11/4986 DOI: $10.6007 /$ IJARBSS/v8-i11/4986

Received: 21 Oct 2018, Revised: 13 Nov 2018, Accepted: 23 Nov 2018

Published Online: 28 Nov 2018

In-Text Citation: (Zulkepli, Tajuddin, Atan, \& Khaja, 2018)

To Cite this Article: Zulkepli, N., Tajuddin, S. N. A. A., Atan, A., \& Khaja, F. N. M. (2018). A Study on Autonomous Use of Technology for Language Learning Among ESL Learners at Tertiary Level. International Journal of Academic Research in Business and Social Sciences, 8(11), 1093-1107.

\section{Copyright: (C) 2018 The Author(s)}

Published by Human Resource Management Academic Research Society (www.hrmars.com)

This article is published under the Creative Commons Attribution (CC BY 4.0) license. Anyone may reproduce, distribute, translate and create derivative works of this article (for both commercial and non-commercial purposes), subject to full attribution to the original publication and authors. The full terms of this license may be seen

at: http://creativecommons.org/licences/by/4.0/legalcode

Vol. 8, No. 11, 2018, Pg. 1093 - 1107

http://hrmars.com/index.php/pages/detail/IJARBSS

JOURNAL HOMEPAGE

Full Terms \& Conditions of access and use can be found at http://hrmars.com/index.php/pages/detail/publication-ethics 


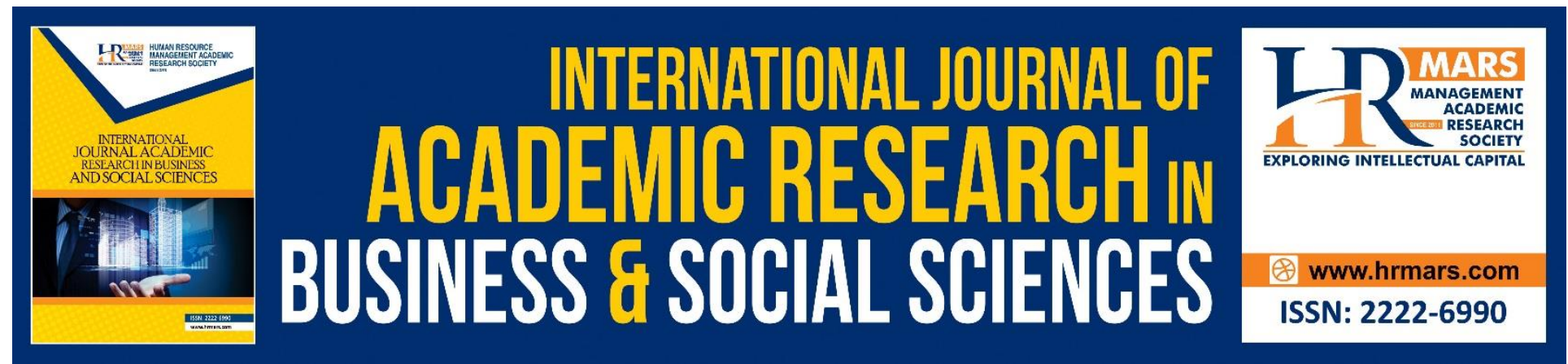

\title{
A Study on Autonomous Use of Technology for Language Learning Among ESL Learners at Tertiary Level
}

\author{
Noraini Zulkepli \\ English Language and Literature Dept., Faculty of Languages and Communication \\ Sultan Idris Education University \\ Email: noraini@fbk.upsi.edu.my
}

\begin{abstract}
Siti Nor Amalina Ahmad Tajuddin
Department of Communication and Media, Faculty of Languages and Communication

Sultan Idris Education University

Email: sitinoramalina@fbk.upsi.edu.my
\end{abstract}

Azizah Atan

English Language and Literature Dept., Faculty of Languages and Communication

Sultan Idris Education University, azizah.atan@fbk.upsi.edu.my

Email: Azizah.atan@fbk.upsi.edu.my

Farah Natchiar Mohd Khaja

English Language and Literature Dept., Faculty of Languages and Communication

Sultan Idris Education University,

Email: farah.natchiar@fbk.upsi.edu.my

\begin{abstract}
Acknowledging the importance of autonomous language learning with technology as an essential skill for lifelong learning, the current study was carried out to investigate whether a group of tertiary level ESL learners were able to self-direct their use of technology for effective language learning experience. The mixed-methods approach was employed to understand the phenomenon. Findings indicate that the most preferred Web 2.0 technology for language learning is the online exercises/quizzes. This is followed by online discussion/forum, public
\end{abstract}


INTERNATIONAL JOURNAL OF ACADEMIC RESEARCH IN BUSINESS AND SOCIAL SCIENCES Vol. 8, No. 11, Nov, 2018, E-ISSN: 2222-6990 @ 2018 HRMARS

websites, blogs, and online video/audio. It could be concluded that even though these ESL learners were able to locate and select the various technologies for autonomous language learning, their main choices seemed to be restricted to the conventional ones. Thus, it is suggested that teachers should play their roles in guiding learners at tertiary level on how to utilize these technologies so that they can optimize their autonomous use of technologies for more meaningful language learning.

Keywords: ESL autonomous learning, self-directed, technology, lifelong learning, higher education

\section{Introduction}

Guided by the 10 Shifts as stated in the Malaysian Education Blueprint 2015-2025, the country is currently in the process of improving the quality of its higher education system, and one of the aims is to produce graduates who can meet the challenges of the $21^{\text {st }}$ century (Ministry of Education 2015). Romero (2015) asserts that one of the ways to meet these challenges is by getting individuals to engage in lifelong learning. Lai, Yeung and $\mathrm{Hu}$ (2015) postulate that lifelong learning requires three important skills: learning and innovation skills, digital literacy skills, and career and life skills, and that these skills can be acquired through "the capacity to engage in self-directed lifelong learning" (Trilling \& Fadel 2009; as cited in Lai ibid. pg: 1).

In line with the above argument, one cannot deny the importance of supporting learners to become autonomous; learners who are able to take responsibility of their own learning (Little 2007; Oxford, 2008). Citing the works done by influential scholars in the field of autonomy and language learning such as Benson (2011), Garrison (1997), and Stolk, Martello, Somerville and Geddes (2010); Lai et al. (2015) conclude that there are two dimensions of learner autonomy. The first dimension concerns one's ability to self-regulate his or her own learning, and the second dimension is one's willingness to regulate one's learning process. It needs to be highlighted that both dimensions value learners' autonomous engagement with language learning opportunities across settings and contexts. In terms of autonomous use of technology for language learning, Bailly (2011) and Lai (2013) highlight the importance of three skills: the ability to locate, select, and use technology meaningfully for language learning. The present study seeks to find out whether a group of ESL learners at tertiary level are able to autonomously use technology for language learning by effectively locating and selecting the various Web 2.0 technologies

A survey carried out by the Malaysian Communications and Multimedia Commission reveals that youths between the ages of 20-24 are the most active users of the Internet (MCMM 2017). In terms of the level of education among the Internet users in the country, the survey further shows that students at tertiary level are the second active users (MCMM, ibid.). With reference to the use of English on the Internet, a survey in 2017 shows that English is the most used language online (statisca.com). Due to the plethora of opportunities to learn the target language, and the fact that students at tertiary level actively use the Internet, one can assume that mastery of English among this group of ESL learners is good. Yet, one of the major issues faced in the country is the low standard of English among the youth; especially the fresh graduates that could cost them their job opportunities (Jobstreet 2015). Thus, the main purpose of the 
present study is to find out whether a group of ESL learners in a public university in Malaysia has the required skills to effectively self-direct their language learning process with technologies. Specifically, it addresses the following research questions:

i. Which Web 2.0 technologies do ESL learners find useful for language learning?

ii. What are the reasons for their choices of Web 2.0 technologies for language learning?

This study is framed within the social view of learning (Vygotsky 1978; Wertsch 1985) focusing on two important tenets. The first one is the mediated mind. According to Vygotsky (ibid.), our participation in a social activity is mediated by physical and symbolic artefacts (Lantolf and Johnson 2007). Some examples of physical artefacts are newspapers, computers, and books, while symbolic artefacts include language, numbers, and technologies. The second tenet is the social nature of learning. Vygotsky (ibid.) regards the basic foundation of learning is that it is social in nature. Learning does not occur in the mind of the individual. In essence, he views social interaction as the foundation for learning. It happens first in the interaction with others (interpsychological category) then it moves to the internal plane i.e. the mind (intrapsychological category).

Based on Vygotsky's social view of learning, three observations can be made about learning. First, learning requires engagement with resources. In this study the various internet environments are the symbolic artefacts, some examples include online videos, online chats, online games and many more. Second is Vygotsky's assertion that learning takes place in social relations. These social relations happen in everyday activity, as aptly described by Zuengler and Miller (2006: 37): "Participaton in these activities (everyday life activities) is both the product and the process of learning". These social relations also occur everywhere, and are not constrained to any one specific location. Thus, learning does not happen only in the classroom. Even when the learner works alone at home, such as when she watches a YouTube video in English, the particular resource that she is engaged with has been socially constructed. Therefore, she is still in a way, participating in a social activity. Third is the recognition of learners as agents who "actively engage in constructing the terms and conditions of their own learning (Lantolf \& Pavlenko 2001: 145). From this view of learning, learners are not seen as passive individuals. Instead, they are viewed as active agents, who are capable of making decisions. In the present study, learners actively make decisions on the types of internet environments that they wish to engage with in order to learn the target language.

\section{Research Methodology}

In order to answer the research questions, the mixed-methods study was chosen as it enabled the researchers to gain complementary data from both the quantitative and the qualitative research tools to understand the issue being investigated. The participants in this study were 289 Year One local students in a Public University in Malaysia from 11 programmes- Malay Literature, Malay Language, TESL, Social Communications, Arabic Language, Chinese Language, Tamil Language, Sports Science, Information Technology, Mathematics and Arts. There were 66 (22.8\%) male students and 223 (77.2\%) female students. Their ages were between 20 to 26 years old. 
For the quantitative data, an adapted questionnaire designed by Winke and Goertler (2008) was adapted and used. Section A of the questionnaire asked for demographic information, Section B consisted of items on the learners' preferred internet environments, and Section C was an open-ended questions that required the learners to explain why they preferred some Internet environments for language learning. The paper-based questionnaire was piloted on 32 learners. The Cronbach's Alpha was an excellent value of 0.932. The questionnaires were then distributed to the participants and the survey took place for a duration of two weeks. Descriptive statistical measures were used to check the frequencies, means and standard deviations of the variables in the questionnaires.

The qualitative data for this study were obtained from the open-ended section of the questionnaire as well as the interview. A total of fifteen students took part in the interview. In order to ensure that the true identity of all participants was kept anonymous, direct references were not made (Cohen, Manion \& Morrison, 2007). Data from the open-ended section of the interview and the semi-structured were both analysed simultaneously. All interviews were transcribed verbatim. The responses were read and carefully re-read, then coded using open coding techniques (Creswell 2013).

\section{Results and Discussion}

The results and discussion are presented based on the two research questions that guide the study.

Research Question 1: Which Web 2.0 technologies do ESL learners find useful for language learning?

The participants in this study were instructed to specify their use of Web 2.0 technology by determining which technology they use for their personal life, learning English or both. A list of 12 common Web 2.0 technologies was provided in the questionnaire and this is presented in Table 1 below. 
INTERNATIONAL JOURNAL OF ACADEMIC RESEARCH IN BUSINESS AND SOCIAL SCIENCES

Vol. 8, No. 11, Nov, 2018, E-ISSN: 2222-6990 @ 2018 HRMARS

Table 1

Web Technology Use for Personal Life and Learning English

\begin{tabular}{|c|c|c|c|c|}
\hline Web 2.0 Technologies & $\begin{array}{l}\text { I use this for } \\
\text { my personal } \\
\text { life. }\end{array}$ & $\begin{array}{l}\text { I think this is/ } \\
\text { would be } \\
\text { useful for } \\
\text { learning } \\
\text { English. }\end{array}$ & Both & None \\
\hline Public websites & $\begin{array}{c}68 \\
(23.5 \%)\end{array}$ & $\begin{array}{c}174 \\
(62.5 \%)\end{array}$ & $\begin{array}{c}41 \\
(14.2 \%)\end{array}$ & $\begin{array}{c}6 \\
(2.1 \%)\end{array}$ \\
\hline Blogs & $\begin{array}{c}114 \\
(39.4 \%)\end{array}$ & $\begin{array}{c}141 \\
(48.8 \%)\end{array}$ & $\begin{array}{c}23 \\
(8 \%)\end{array}$ & $\begin{array}{c}11 \\
(3.8 \%)\end{array}$ \\
\hline Wikis & $\begin{array}{c}56 \\
(19.4 \%)\end{array}$ & $\begin{array}{c}192 \\
(66.4 \%)\end{array}$ & $\begin{array}{c}23 \\
(8 \%)\end{array}$ & $\begin{array}{c}18 \\
(6.2 \%)\end{array}$ \\
\hline Email & $\begin{array}{c}190 \\
(65.7 \%)\end{array}$ & $\begin{array}{c}62 \\
(21.5 \%)\end{array}$ & $\begin{array}{c}34 \\
(11.8 \%)\end{array}$ & $\begin{array}{c}3 \\
(1 \%)\end{array}$ \\
\hline Online Chat & $\begin{array}{c}193 \\
(66.8 \%)\end{array}$ & $\begin{array}{c}50 \\
(17.3 \%)\end{array}$ & $\begin{array}{c}37 \\
(12.8 \%)\end{array}$ & $\begin{array}{c}9 \\
(3.1 \%)\end{array}$ \\
\hline Online messaging & $\begin{array}{c}208 \\
(72 \%)\end{array}$ & $\begin{array}{c}33 \\
(11.4 \%)\end{array}$ & $\begin{array}{c}44 \\
(15.2 \%)\end{array}$ & $\begin{array}{c}4 \\
(1.4 \%)\end{array}$ \\
\hline Online conferencing & $\begin{array}{c}135 \\
(46.7 \%)\end{array}$ & $\begin{array}{c}116 \\
(40.1 \%)\end{array}$ & $\begin{array}{c}13 \\
(4.5 \%)\end{array}$ & $\begin{array}{c}25 \\
(8.7 \%)\end{array}$ \\
\hline $\begin{array}{l}\text { Online social networking } \\
\text { (e.g. Facebook) }\end{array}$ & $\begin{array}{c}156 \\
(54 \%)\end{array}$ & $\begin{array}{c}77 \\
(26.6 \%)\end{array}$ & $\begin{array}{c}50 \\
(17.3 \%)\end{array}$ & $\begin{array}{c}6 \\
(2.1 \%)\end{array}$ \\
\hline $\begin{array}{l}\text { Online discussion boards/forum (e.g. } \\
\text { linguaholic.com/ esl.cafe.com) }\end{array}$ & $\begin{array}{c}45 \\
(15.6 \%)\end{array}$ & $\begin{array}{c}211 \\
(73 \%)\end{array}$ & $\begin{array}{c}15 \\
(5.2 \%)\end{array}$ & $\begin{array}{c}18 \\
(6.2 \%)\end{array}$ \\
\hline $\begin{array}{l}\text { Online digital video/audio } \\
\qquad \text { (e.g. YouTube/Instagram) }\end{array}$ & $\begin{array}{c}96 \\
(33.2 \%)\end{array}$ & $\begin{array}{c}129 \\
(44.6 \%)\end{array}$ & $\begin{array}{c}52 \\
(18 \%)\end{array}$ & $\begin{array}{c}12 \\
(4.2 \%)\end{array}$ \\
\hline Online computer games & $\begin{array}{c}157 \\
(54.3 \%)\end{array}$ & $\begin{array}{c}90 \\
(31.1 \%)\end{array}$ & $\begin{array}{c}21 \\
(7.3 \%)\end{array}$ & $\begin{array}{c}21 \\
(7.3 \%)\end{array}$ \\
\hline $\begin{array}{l}\text { Online exercises/quizzes } \\
\text { (e.g. englishforeveryone.org) }\end{array}$ & $\begin{array}{c}45 \\
(15.6 \%)\end{array}$ & $\begin{array}{c}212 \\
(73.4 \%)\end{array}$ & $\begin{array}{c}25 \\
(8.7 \%)\end{array}$ & $\begin{array}{c}7 \\
(2.4 \%)\end{array}$ \\
\hline
\end{tabular}

Notes: $\mathrm{N}=289$ 
Of the 289 responses obtained, a majority indicated that online exercises and quizzes (73.4\%), online discussion forums (73\%), wikis (66.4\%), public websites (62.5\%) and blogs (48.8\%) were the five technologies they found most useful for learning English. The responses show that learners are more likely to find technologies that were specifically designed for language learning as more useful as compared to technology that are commonly used for purposes other than language learning. This is evident as they regard online exercises and quizzes to be the most useful Web2.0 technology for learning the English language.

From the data collected, it is also revealed that there are some Web 2.0 technologies that the participants of this study find least useful for learning English. The data show that online messaging (11.4\%) is found to be among the least useful for learning English followed by online chat (17.3\%) and email (21.5\%). Incidentally, technologies such as online messaging and chat are more commonly used for daily communication whereby slang, short forms and even native languages are used. They are also not technologies that are introduced in classrooms as part of a formal approach for language learning.

Research Question 2: What are the reasons for their choices of Web 2.0 technologies for language learning?

Online exercises/quizzes

Through the students' responses in the questionnaire, the highest majority 211 learners which represented $73.0 \%$ selected online exercises/quizzes as the most useful for learning English. Learners L56 and L58 acknowledged the advantage of available answers and brief yet easily understood explanations to wrong answers provided through online exercises.

I use this website to test my knowledge about the language. It can be about grammar or vocabulary. This online quizzes also provide answers. Hence, I can improve my language. For example, British council (L56)

Online exercises/ quizzes help me to learn English. I can practice my English by doing the online exercises. It helps me to overcome my problem like grammar. I also likes the explanation given when I answered the question wrong. The explanation is brief and easy for me to comprehend (L58)

In addition, another advantage of such exercises was that they did not consume a lot of time and students were able to obtain their scores immediately.

With the advanced technology today, I can just do exercises online to sharpen my English skills. This online exercises are far more easily to use and doesn't consume a lot of time. I could also get my marks straight away (L68).

Learner 213 stated that she improved on several aspects of English such as grammar and writing skills. 
Helps me to improve my grammar. By taking online exercises, it will make my writing better than before. It will also help to improve my assignment and essay. By taking online exercises, it will teach me the correct grammar in my writing (L213).

An interesting advantage of doing online exercises and quizzes was that they contained elements of fun and entertainment which motivated Learner 83.

Through online exercises and quizzes, we can learn English effectively. Some exercises and quizzes are fun and entertaining. By doing English exercises and quizzes will boost up our emotion, happiness. When we do stuffs in the state of happiness, we will learn and improve effectively. (L83)

Online discussion boards/forums

The second highest ranked internet environment for language learning was the use of online discussion boards/forums with a score of $73.4 \%$ by 211 learners. $L 83$ pointed out two positive aspects of online discussion boards/forums such as learning sentence structures from postings and stated that she tried to ensure that her postings were grammatically correct. Another learner L113, argued that by reading the opinions of others, she improved her English. She also mentioned that the language used in such environments were of a higher level and thus she often learned new words.

Online discussion boards / forums - by using this web technologies, I can improve my English by reading others opinions. I also can share my opinion and I will try to use an appropriate word to do so. Usually, forum are based on high language, thus I will try to search the meaning of certain words and I will learn some of new words that I found (L113)

One learner indicated that she gained a lot of new information because people who were part of online discussion groups were from different parts of the world and they have different perspectives regarding matters. Additional advantages were learning from what others think about a specific topic and the possibility of exchanging ideas regarding different areas such as politics, economics and education.

These types of platform are giving us more information. And this will give us so much of knowledges that we never might think about. We could think more viewers throughout others perspective (L221).

Online discussion board / forum - I learn English through this technologies by posting my answers and the other students in the forum will put on their comment(L64).

Online discussion board / forum - we can exchange our ideas about politics, economics and education. Our language skills will develop faster (L117). 
Wikis

Wikis came in third where 192 learners which contributed to $66.4 \%$ indicated this web technology as useful for language learning. Learners emphasized how fast and easy it was using wiki when they need to look for meaning of words. They mentioned the easy and quick access at any time using the mobile phones instead of the traditional dictionary, the availability of explanations and a favourite tool to find out meanings of new words.

Wikis - almost students depends on wikis to find the meaning of some words in English. It is because we use Internet in very long hours and using wikis on the spot to understand something. Besides dictionary, wikis is easy to read without bringing a heavystuffs like dictionary and only use handphone everywhere. But using dictionary, it only explains the words in very short way such as only give the meaning not explaining like wikis (L223).

Wikis - second most useful web 2.0 technology as wikis dominate as the top search of most of the thing we are looking for. We could easily found the meaning of words and short summary of an organization. Frankly speak, most of the wikis are quite useful yet could not be fully trusted (L81).

I feel wikipedia is a very important tool improve our English as I always go through it to find meanings of words or terms that I don't understand. It is also a reliable source of information as information uploaded in wikis are usually checked and edited before it is published online (L66).

However, the learners were aware that the information displayed in wiki was not totally reliable. Although the information needed to be verified especially when referred to in assignments, wiki was still indispensable to be used as a reference.

Wikis - For research purpose. Though it lack credibility, it is the most resourceful website that I can find. I can understand wikis better if it in English. So, it increase my vocabulary. (L137)

Wikis - provide many good information that can be trusted and it also provide many details about the information. I often use it in class and for assignment purpose. (L286)

Wikis - I use wiki because I read so many histories and new information for the sake of my assignment and at the same time, I learn English language via wikis (L215)

Public websites

The use of public websites for learning English came in fourth with 174 (62.5\%) learners acknowledging these as useful sources. Learners L25 and L62 indicated that she used public websites when writing essays as she was able to obtain different ideas and information pertaining to specific topics. She also utilised Google Translate to spell check her work. 
INTERNATIONAL JOURNAL OF ACADEMIC RESEARCH IN BUSINESS AND SOCIAL SCIENCES

Vol. 8, No. 11, Nov, 2018, E-ISSN: 2222-6990 @ 2018 HRMARS

Public websites very useful for me to looking / searching an essay when I am doing an assignment. It is also very helpful because public websites is unlimited about its content (L25)

I often used public websites when I want to write an essay. I gained many ideas to make my essay looks more interesting and informational. I also used Google Translate to check my spelling (L62)

Two students mentioned the useful information available in public websites as compared to books. They also asserted that the information was quick to access and a lot of information pertaining to education was available from these public websites.

Public websites - many useful things or information can be found other than books. Quick access and lots of education things can be find (L143).

Public websites - very helpful for students to learn something easily. Whatever, the student searching for they will get in a second in public websites. So they no need to waste their time by searching things at library (L182).

Learner L221 regarded public websites as her first preference of Web 2.0 technologies for self-regulated language learning because of the abundance of information available in a short time. In addition, there were also many choices of websites which presented similar information regarding specific topics available.

Public websites my first choice of learn English usefully because I felt that so many things and knowledge could gain just simple in a short time. And I felt if easier to understand as we wanted because there are so many pages where we can always refer to (L221)

Blogs

Through the students' responses in the questionnaire, Blogs came in fifth highest whereby 141 (48.8\%) indicated Blogs as the most useful for learning English. Not only that, out of the six highest ranked technologies, Blogs scored the highest for use for personal life, which is 114 or $39.4 \%$.

L25 was of the opinion that Blogs contain a variety of discussion topics and that she could read opinion of others regarding a particular topic. L79 believed that she gained a lot by reading about health, education and inspiring stories from different Blog writers.

Blogs. It is very easy for me to use it. Because some of the contains or topic are in these blog is very easy to find and blogs like a discussion forum. I can see the comments from the blogs from the others people about their opinions in some topics such as education (L25) 
I choose blogs because I like to read blogs a lot since many inspiring writer are mostly from blog I guess. Lot of kinds of blogs such as health, education and inspiring success stories are good to read (79)

L194 regarded blogs as a great way to learn English especially by reading personal blogs by students, writers and journalists. She considered these writings as interesting as they depicted the inner thoughts of the writers. Also, she liked how Blog writers display creativity with the play of words.

Blogs - I find that blog is a great way to learn English especially by reading personal blogs by students, writers and journalist. As writing is subjective, it is very interesting to read on how other minds work and how they play with words (L194)

One student believed that engagement with Blogs helped her to want to share personal experiences with others from different parts of the globe. In addition, she felt relaxed learning through Blogs.

Blog is quite similar to essay writing or diary where I can share my experience and useful knowledge with all people around the world. I can also share good reading passage written by others to improve my skills and knowledges. I feel relax to use blog at the same time I can learn English (L46)

Online digital video/audio

The use of online digital video/audio for learning English ranked sixth with 129 (44.6\%) stating it as useful. Learners considered the availability of sound and visuals as added values of digital videos and audios. They learned a lot through watching English movies or songs.

Online digital video / audio - learn from a lot of English's movies or songs. Spend more time in this web (Youtube). Can improve my hearing and reading skills in this web. Learn from a lot of talk by a professional speaker (L219)

Watching and listening to Youtube or other online digital audio apps or website, I'm improving my English slowly as I learned new words, improving my English speaking skill and gain knowledge from the video or song that explained everything in English (L2)

I will learn from watching the video or songs by memorizing the lyrics and try to understand what they say without subtitle (L166)

L221 regarded watching videos as time saving as compared to reading about the same topic. Apart from saving time, learners also pointed out the advantage in improving pronunciation and speaking skills (L55) and also improving both English language and Mathematical skills when watching video tutorials (L79).

Online digital video / audio - because as usually everyone will find out the way knowing easier throughout video. This because more easier than we spend our time in reading 
INTERNATIONAL JOURNAL OF ACADEMIC RESEARCH IN BUSINESS AND SOCIAL SCIENCES

Vol. 8, No. 11, Nov, 2018, E-ISSN: 2222-6990 @ 2018 HRMARS

for an hours instead we can make it in just 6 or 5 minutes by watching online videos (L221)

Online digital video / audio - I always trying to find videos from Youtube to improve my English language. For example, I always find videos about grammar, speaking practice, short story and songs. It makes my language learning easier and fun (L55)

As a student who takes mathematics courses, besides learning in class, we also learn by ourself by watching tutorials videos in Youtube. Most videos are in English language, so we are practically learning mathematics and English language at the same time. In order to understand the video, we have to understand English first (L79)

I use YouTube in order to get further details about some topic discussed in my class (L286)

Learners indicated that online exercises and quizzes, online discussion boards/forums, wikis, public websites, blogs, and online digital video/audio were the technologies they found most useful for learning English. The advantages mentioned focussed on the availability of instant access, abundance of information and creative presentations. Specific areas mentioned included the improvement of language skills such as reading, writing, vocabulary increase and speaking/ pronunciation skills. Other interesting factors were that they could read and exchange ideas pertaining to specific topics with both local and international audiences. However, other forms of web technologies such as WhatsApp, Online messaging/chats, E-mails and social networking were regarded as more related to communications as these were listed to be useful and more suited for personal life.

The usefulness of online exercises/quizzes for learning English was the highest ranked because of the availability of instant feedback and explanation of incorrect answers. Information and communication technology (ICT) plays a critical role in students' learning engagement and improvements by providing them with learning support through the use of instant feedback and asynchronous feedback facilitated by online, mobile, learning tools. Wong and Yang (2017) affirmed the capacity of ICT for generating instant feedback and asynchronous feedback, which enhanced students' learning engagement, collaborative knowledge building, and autonomy as active learners.

Two learners made comments highlighting how they related between formal learning and informal learning as complementary, which supports Greenhow and Robelia's (2009) assertion. They stated that what was learned formally could be supported by informal learning outside the lecture rooms especially with public websites and Wikis. This was also true of Wikis when L62 and L255 stated of how it helped them look for information pertaining to their assignments. Miyazoea and Anderson (2012) found that forum discussion, blogs and wikis were effective ICT tools for promoting writing skills and their study concluded positive effects of forums and blogs on language learning.

One of the recurring responses to the use of Blogs as useful sources of English language learning was the variety of discussion topics available and that these were opinions and views from users around the 
world. For example L46 mentioned how she could share her thoughts, experience and knowledge with others. Another learner, L79 stated how she learnt new information pertaining to different topics which were inspiring. This is similar to Sockett and Toffoli (2012) who stated that when learners participate in virtual communities with other English users, opportunities arise to use the language in real contexts.

Lastly, learners focussed on the characteristics of online digital video/audio such as YouTube as the main reasons why they preferred these as learning resources. Among the advantages mentioned by learners were that the audios and videos assisted in the improvement of pronunciation and speaking skills. Learner L221 talked about time saving as compared to reading when learning about specific skills. Another important advantage of digital video/audio is that a student, she had the opportunity to students to listen to and gain knowledge from the professionals or experts from another part of the world (L219). Jones and Cuthrell (2011) discussed the use of YouTube videos to introduce more difficult subject matter, to illustrate a point during a lesson or to review concepts taught. This was mentioned by L286 when she admitted referring to YouTube to gain further details about topics learnt in class.

\section{Conclusion}

The main purpose of the study is to find out whether a group of ESL learners at tertiary level in Malaysia possesses the required skills to locate and select the appropriate Web 2.0 technologies for autonomous language learning; which is essential for lifelong learning. Based on the findings, it can be concluded that to a certain extent these ESL learners have the skills to self-regulate their language learning via the use of different Web 2.0 technologies. However, there is a noteworthy concern about their choices of Internet environments: this group of ESL learners tend to choose conventional technologies for language learning. Even though the findings show that these learners are aware of the availability of various types of Internet platforms, their choices of those that are useful for language learning seem to be restricted to the ones that are designed specifically for language learning i.e. online exercises, quizzes and discussion forums. This somehow reflects that they are not able to fully optimise the opportunities available for quality language learning. This is where ESL teachers need to play their roles by providing support and guidance on how to utilize the various Web 2.0 technologies so that learners will be able to self-direct their language learning experience effectively.

With the rise of the internet and new communication technologies, language learning has moved beyond the classroom walls. Opportunities for the incidental as well as the deliberate practice of English have multiplied and far exceeded what can be done in more formal environments. Current technology provides new opportunities to increase the effectiveness of language learning and teaching. Based on the rapidly changing evolution of technology, it is important for language teachers and educators at different levels to recognize how to effectively and efficiently integrate technology into their curriculum design. This will not only help students acquire the second language easily, but also successfully enhance their self-regulated language learning. 
INTERNATIONAL JOURNAL OF ACADEMIC RESEARCH IN BUSINESS AND SOCIAL SCIENCES

Vol. 8, No. 11, Nov, 2018, E-ISSN: 2222-6990 C 2018 HRMARS

\section{Funding Acknowledgement}

This work was supported by University Research Grant Universiti Pendidikan Sultan Idris [Grant Reference Number: 2016-0196-106-01].

\section{Corresponding Author}

Noraini Zulkepli

Department of English Language and Literature, Faculty of Languages and Communication

Sultan Idris Education University

Email: noraini@fbk.upsi.edu.my

\section{References}

Bailly, S. (2011). Teenagers learning language out of school: What, why and how do they learn? How can school help them?. In P. Benson, \& H. Reinders (Eds.), Beyond the language classroom (pp. 119_131). New York, NY: Palgrave Macmillan.

Benson, P. (2011). Language learning and teaching beyond the classroom: An introduction to the field. In P. Benson, \& H. Reinders (Eds). Beyond the language classroom (pp. 7_16). New York: Palgrave Macmillan.

Cohen, L., Manion, L., and Morrison, K. (2007).. Research methods in education. (6 ${ }^{\text {th }}$ ed.) London: Routledge.

Creswell, J.W. (2013). Qualitative inquiry \& research design: choosing among five approaches. London: Sage.

Garrison, D.R. (1997). Self-directed learning: Toward a comprehensive model. Adult Education Quarterly, 48(1), 18-33.

Greenhow. C. \& Robelia, B. (2009). Informal learning and identity formation in online social networks. Learning, Media and Technology. 34(2), 119-140.

Jobstreet (2015) https://www.jobstreet.com.my/career-resources/employers-fresh-graduatesunrealistic-expectations/ Accessed: 30 th Sept 2018.

Jones, T. \& Cuthrell. K. (2011). YouTube: Educational potentials and pitfalls. Computers in the schools. 28(1), 75-85.

Lai, C. (2013). A framework of developing self-directed technology use for language learning. Language Learning \& Technology, 17, 100_122.

Lai, C., Yeung, Y., \& Hu, J. (2015). University student and teacher perceptions of teacher roles in promoting autonomous language learning with technology outside the classroom. Computer Assisted Language Learning, 29(4), 703-723.

Lantolf,.P. and Pavlenko, A. (2001). (S)econd (L)anguage (A)ctivity theory: understanding second language learners as people. In Breen, M.P, Learner contributions to language learning. (pp 141-59). Harlow: Pearson Education Limited. 
INTERNATIONAL JOURNAL OF ACADEMIC RESEARCH IN BUSINESS AND SOCIAL SCIENCES Vol. 8, No. 11, Nov, 2018, E-ISSN: 2222-6990 @ 2018 HRMARS

Lantolf, J.P. and Johnson, K.E. (2007). Extending Firth and Wagner's (1997) Ontological perspective to L2 classroom praxis and teacher education. The Modern Language Journal, 91, 877-892.

Little, D. (2007). Language learner autonomy: some fundamental considerations revisited. Innovation in Language Teaching and Learning, 1(1), 14-29.

Romero, M. (2015). Work, games and lifelong learning in the 21st century. Procedia-Social and Behavioral Sciences, 174, 115-121.

MCMC (2017) Internet Users Survey. Retrieved from:

https://www.mcmc.gov.my/skmmgovmy/media/General/pdf/MCMC-Internet-Users-

Survey-2017.pdf accessed July 4th 2018

Ministry of Education (MoE) (2015). Malaysia Education Blueprint 2015-2025 Higher Education (MEBHE). Putrajaya: Ministry of Education Malaysia.

Miyazoea, T \& Anderson, T. (2012). Discuss, reflect and collaborate: A qualitative analysis of forum, blog, and wiki use in an EFL blended learning course. Procedia-Social and Behavioural Sciences, 34, 146-152.

Oxford, R. (2008). Hero with a thousand faces: learner autonomy, learning strategies and learning tactics in independent language learning. In Hurd, S. \& Lewis, T. (Eds). Language learning strategies in independent settings, (pp. 41-67). Bristol: Multilingual Matters.

Statistics Portal. https://www.statista.com/statistics/262946/share-of-the-most-common-languageson-the-internet/ Accessed: $28^{\text {th }}$ October 2018.

Sockett, G., \& Toffoli, D. (2012). Beyond learner autonomy: A dynamic systems view of the informal learning of English in virtual online communities. ReCALL,24(2), 138-151. 151.DOI:10.1017/S0958344012000031.

Stolk, J., Martello, R., Somerville, M., \& Geddes, J. (2010). Engineering students' definitions of and responses to self-directed learning. International Journal of Engineering Education, 26(4) , 900-913.

Vygotsky, L.S. (1978). Mind in society: the development of higher psychological process. London: Harvard University Press.

Warschauer, M., \& Grimes, D. (2007). Audience, authorship, and artifact: The emergent semiotics of Web 2.0. Annual Review of Applied Linguistics,27, 1-23.

Wertsch, J.V. (1985). Culture, communication, and cognition: Vygotskian perspectives. Cambridge: Cambridge University Press.

Winke, P., \& Goertler, S. (2008). Did we forget someone? Students' computer access and literacy for CALL. $\quad$ CALICO Journal, 25 (3), 482-509.

Wong, G. K. W., \& Yang, M. (2017). Using ICT to Facilitate Instant and Asynchronous Feedback for Students' Learning Engagement and Improvements. In Emerging Practices in Scholarship of Learning and Teaching in a Digital Era (pp. 289-309). Springer, Singapore.

Zuengler, J. and Miller, E.R. (2006) Cognitive and sociocultural perspectives: two parallel SLA worlds? TESOL Quarterly, 40 (1), 35-58. 